\title{
"Why Are We Here?": Teaching of Phenomenon of Migration with Oral History ${ }^{i}$
}

\author{
Ilker Dere \\ Department of Social Studies Education, Necmettin Erbakan University, Konya, Turkey
}

Copyright $\mathrm{C} 2018$ by authors, all rights reserved. Authors agree that this article remains permanently open access under the terms of the Creative Commons Attribution License 4.0 International License

\begin{abstract}
The aim of this study was to determine whether oral history is an effective method for teaching the phenomenon of migration. In this study, the action research was used to discuss the phenomenon of migration in detail and to solve the problems that may be encountered during the teaching process. Oral history interviews, self-evaluation forms, and unstructured questionnaires were used for data collection. The obtained data were evaluated and interpreted by using content analysis and descriptive analysis methods. The results of the study show that the students learned economic, sociological, cultural and personal dimensions of migration in detail. In addition, students found that migrations are more likely to be caused by economic conditions and that their families were satisfied with their new lives after migration. In addition, migration study has made important contributions to the students to learn their family's migration history, to compare the past and present economic conditions, get to know the family better and understand the phenomenon of migration correctly.
\end{abstract}

Keywords Oral History, Migration, Social Studies, Historical Thinking Skills

\section{Introduction}

Migration refers to the movement of people from one place to another for various reasons. People leave their countries and usually do not return. These two important features differentiate migration from other types of movements. At this point, there are three main motives for migration, namely: (i) to settle permanently in another country, (ii) to stay in that country for a long period of time and (iii) to migrate again. The definition of traditional migration is usually based on the first motive [4].

On the other hand and in a more general sense, migration is the movement by people from one place to another in a certain time for social, economic, cultural and political reasons [12]. In fact, migration is not only the change of geographical location it is also a population movement that changes the social structure through its social, economic, cultural and political dimensions [25].

\subsection{Causes of Migration}

People can migrate from one place due to economic, social and political reasons. Nowadays, people migrate from villages to cities or from one country to another, due to economic reasons, such as more job and employment opportunities [19]. The reasons of migration in Turkey are as follows: rural areas are less developed than cities, and people want to have social security, intend to increase their living standards, desire to get rid of terror, mechanization in agriculture, uninviting conditions of rural areas, attractive opportunities in the city, rapid progress of industrialization in some cities, and so on $[1,5,25,38]$.

\subsection{Consequences of Migration}

There are positive and negative consequences of migration. As a positive consequence, it enables communities to mix through marriages and other means. Moreover, it brings changes along with it. Migrants and local people with different traditions, attitudes and behaviors must accept or learn the traditions and customs of another side in order to live together. Furthermore, migrants change the environment in which they settle while they socialize. Migration questions the traditions, customs, and social order. It also provides new personality and identity to migrants [19]. Finally, it paves the way for development. Such development brings prosperity within time, although it requires time and effort [5].

In addition to positive consequences, there are also negative consequences of migration. Social and cultural discrepancies, economic recession in the region, interregional imbalance, ethnic and cultural problems, exclusion, discrimination, lack of service, state dependency and passivity, squatting, citizenship, and congregation are examples of negative consequences 
$[5,25,27]$

\subsection{Types of Migration}

Migration may be classified as free migration, forced migration, seasonal migration, permanent migration, internal migration and international (external) migration $[10,25,33]$. Internal migration refers to the movement of people within a country. This type of migration is the internal question of the relevant state and citizenship of the immigrant does not change [4]. Depending on the flow, internal migration might be from rural to urban areas, within urban areas, from urban to rural areas, or within rural areas [39].

On the other hand, external migration refers to the movements made into or out of the borders of a country. This type of migration is qualified as international since it can cover two or more states. An international immigrant gives up his/her original citizenship and accepts the status of 'immigrant' proposed by another state. Sometimes they are not registered, while sometimes they acquire citizenship of the new country [4].

Migration, of which properties and various consequences were stated above, is one of the particular concerns in Turkey. Because of its geographical location, Turkey has been one of the countries that experienced various types of migration for centuries [30]. In 2011, after the outbreak of the Syrian Civil War, millions of Syrian refugees migrated to Turkey. It is now one of the host countries with the greatest number of Syrian refugees in the world [34]. According to the latest information obtained from the Ministry of Interior Directorate General of Migration on 19 July 2018, 3.541.572 Syrian refugees are living in Turkey [27].

Moreover, Turkey has been experiencing a significant internal migration flow from east to west that started in the 1960s. According to the data obtained from Turkey Statistical Institute (TurkStat), 2.619 .403 people changed their places for various reasons in 2016. The province with the highest mobility was Istanbul. Although 369.582 people migrated to Istanbul; 440.889 people left Istanbul. Ankara, İzmir, Kocaeli, and Bursa follow Istanbul in terms of provinces that received the highest number of migrants [35]. The examination of International Migration Statistics issued by TurkStat in 2017 showed that 253.640 people migrated from Turkey in 2017, which corresponds to a 42.5 percent increase, compared to data of 2016. However, the number of migrants arriving in Turkey was 466.33 , and Istanbul has accepted 166.144 migrants [3]. Briefly, internal migration and external migration continue to be one of Turkey's most important agenda.

\subsection{Teaching about Migration}

In Turkey, where both internal migration and external migration are frequently observed, teaching the phenomenon of migration and its various dimensions has become important. In the Turkish education system, migration is a subject in social studies classes in secondary school. Migration was previously included in Grade 7 Social Studies Curriculum in 2005 [23] and is included in the scope of Grade 7 - People, Environments and Places Unit of Social Sciences Curriculum in 2017. The following outcome about the migration is included in the relevant learning domain, along with the settlement, population, and traveling: "Discusses the causes and consequences of migration through case studies." [24].

The phenomenon of migration has economic, sociological, geographical, cultural and psychological dimensions. Therefore, in Turkey, it is taught mostly by using geographical teaching methods and techniques. A literature review has shown that no special method or technique is recommended in the classes on migration. However, in Social Studies Curriculum in 2017, the aim was to offer students the ability to draw and interpret tables, graphs, and diagrams in relevant learning domains, as it gives hints on how to teach this phenomenon. For teaching the same learning outcome (migration), it was proposed to conduct an oral history study in Social Studies Curriculum in 2005. However, this proposal was removed from the Curriculum in 2017 [7]. Nevertheless, in the general explanations of the Curriculum in 2017, "carrying out local and oral history studies on all relevant topics" was recommended. In a sense, social studies teachers who were aware of the potential of oral history in teaching the phenomenon of migration are left open doors.

Although oral history method is not at the forefront in teaching about migration in Turkey, it is frequently used by countries with a large number of migrants, such as the United States, in lessons on the phenomenon of migration and its types. For example, in the United States, syllabuses and course materials designed to facilitate the better understanding of the history of migration and to help teachers, may be found at the Immigration History Study Centre Archives (IHRCA) established in Immigration History Study Centre in the University of Minnesota [16]. In addition, there are various interviews, resources, and syllabuses that teachers may utilize in the Library of Congress, one of the largest libraries in the world. When the relevant oral history materials and collections were examined, it is observed that syllabuses were prepared using interviews made by people who worked as slaves in the past and on Black Thursday [21]. Lastly, the Centre established Archive of Immigrant Voices consisting of oral history interviews made with migrants in Center for Global Migration Studies. This center works in cooperation with the Smithsonian National Museum of American History to assess the status of training about migration and migration history in public schools in the United States. The data obtained in this study is intended to be the basis for the creation of a new framework for migration and teaching about migration throughout the country [2]. 
In Turkey, oral history method has been used by many historians and scholars $[11,14,26,28,32]$ to investigate the phenomenon of migration since the 1990s. In addition, there are many migration study centers. However, many of these centers generally focus on graduate researches and on producing teaching materials related to the phenomenon of migration. These institutions also use oral history interviews; however, they do not conduct studies for instructors and teachers about migration.

Oral history is used as a method in teaching about migration in the United States, a country with a large number of migrants. The history of black people and migrants in the United States has become known thanks to oral history interviews [33]. These experiences were integrated into the field of education to help students to materialize the phenomenon of migration through oral history interviews. In this type of oral history interviews on the phenomenon of migration, children ask their families where they live, why and how they move, how long they have been living there, and what they were engaged in [29]. These questions allow the students to learn about the history of their parents and to understand the causes of migrations and what happens later.

In addition, students utilize family migration maps [10] to investigate the migration history of their families. While they are interviewing with their families, they write that from where they migrated to and that when they have come to the place where they currently live, through a mute map. They further put notes at the edges of the map for the places their relatives currently live and why they have migrated to that place. This activity also improves their ability to perceive space. These kinds of activities help students to address the phenomenon of migration from a historical approach from past to present and form connections with their own family histories.

Oral history method, which has an important potential in teaching about migration, is not a preferred method in Turkey in social studies lessons. In fact, there is no study, where students conduct a study on migration with the oral history method, although oral history in the teaching about migration was proposed to be used in the 2005 Social Studies Curriculum. This study was designed after the current situation, oral history and the content of the migration in the syllabus were evaluated. The aim of this study was to determine whether oral history was an effective method in teaching about migration. In this context, answers to the following study questions were sought:

1- Was the concept of migration learned through oral history method?

2- What were the contributions of oral history practice to the students?

3- What did students learn about migration during oral history interviews?

\section{Methods}

This study was conducted by action research method. Action research can be performed to improve the quality of teaching, to try or introduce new approaches [31]. This method can be conducted either directly by an external researcher or by a practitioner. Researcher contributes to the study in terms of the field of expertise, and practitioner shares his/her activities with the researcher. In this way, they can be in an intense interaction and sharing [39].

By taking the characteristics of action research and collaborating with two social studies teachers into account, the action research process was designed for the teaching about migration. Furthermore, social studies teachers who collaborated throughout the process applied the activities designed by the researcher within the specified period and shared their observations with the researcher.

The students, who were involved in the study, conducted oral history interviews in order to discover the phenomenon of migration. Oral history is one of the data collection tools in historical study. The stories and perspectives of people are recorded by this method. More importantly, this method is integrated into educational implementations as a constructivist learning and teaching method [8].

\subsection{Working Group}

The purposive sampling was used to select the students to be included in the study. This method is preferred to ensure the representability or typicality of the selected individual or events [19]. İzmir and Tekirdağ provinces, which are based on industrial production and receive migrants, were selected. In these provinces, the schools of the children of laborers and migrants were determined. However, social studies teachers of those schools decided which students would participate in the study. As a result, 46 seventh-grade students of two public schools in Tekirdağ and İzmir ( 25 from Tekirdağ and 21 from İzmir) participated in the study. The most important reason for the selection of two different schools was being able to make comparisons. Yet, in some cases, a number of questions are asked about what the differences of a study conducted at a specific school would be if it were carried out in another school. The present study was conducted in two different schools to answer these questions and to create a strong argument that shows what kind of outcomes will be obtained if the oral history method on the same subject is applied in different school conditions.

\subsection{Data Collection Tools}

The data collection tools of the study are the students' oral history interview records, self-assessment forms, and application evaluation questions. These data collection tools were used to see what students learned from source 
people and to learn their views on the work they carried out.

\subsection{Data analysis}

The data collected from Tekirdağ and İzmir provinces were evaluated, interpreted and compared through content analysis and descriptive analysis methods. During the content analysis, oral history interviews and responses to application evaluation questions were coded in study questions. Then, the themes were created by combining the codes. In the descriptive analysis step, data collection tools were examined and quotations to be made were determined During these two steps, the data collected in Tekirdağ and İzmir were interpreted comparatively.

Rules recommended by Maxwell [22] and Johnson [17] were followed to ensure the reliability and validity of the study. The results of the study were evaluated together with the teachers who collaborated during the process. The inconsistencies and inaccuracies determined were corrected. In addition, students' answers to the application evaluation questions and self-evaluation questions and oral history interview records were compared to confirm the information provided.

\section{Findings and Comments}

Content analysis and descriptive analysis methods were used to evaluate students' oral history interviews, their answers to the application evaluation questions and self-evaluation questions. Because of the evaluation, three themes were obtained.

\subsection{The Role of Oral History Method in Teaching about Migration}

Examination of oral history interviews carried out by the students and their answers to the application evaluation questions has revealed the contribution and role of the mentioned method in learning the causes and consequences of migration. The results are presented in Table 1 .

The results given in table 1 show that students understand the reasons why their families migrated and the effects of the migration on their lives in detail. It is possible to understand this from the answers of students to the application evaluation questions. Yunus Emre explained that his father came to İzmir for studying: "I have clearly learned that why my family migrated. [My father] has migrated to Izmir for studying..." he said. Hatice Nur's father migrated to Tekirdağ for job opportunities: " $M y$ parents came to Çerkezköy to work. They have migrated here because of low employment opportunities in Kırlkkale..." Unlike Yunus and Hatice Nur's parents, İrem's mother has migrated to Turkey from Ukraine, because she got married: "My mother migrated from Ukraine in 2014 because she got married." It is also possible to see that Gülay correctly learned the various causes of migration: "I learned that there may be many reasons for migration, for example, for work, for health, and for material-spiritual situations. I learned why my family migrated." Finally, Esra from Tekirdağ group: "Thanks to this interview, I learned how, when and why my father migrated here." Finally, Zeynep Gamze from Tekirdağ Group: “...Before I did this interview, I had not known much or have detailed information about migration. Thanks to this study, now I have an idea about migration." Statements of students are important as they show that the study has achieved its goal.

Students interviewed 46 people during the migration study. Of 46 people, two migrated for studying, one for military service, one due to terrorism, and one for health. The remaining 41 people have left their hometown to get better job opportunities and living standards. It was further detected that people migrating to Tekirdağ mostly came from Central Anatolia, Marmara, and the Black Sea regions, while those who migrated to İzmir came from Southeast Anatolia, Aegean, and Marmara regions. The findings of this theme have shown that oral history interviews enable students in both provinces to explore the economic, sociological, cultural and personal dimensions of migration.

\subsection{Contributions of Oral History Practice to Students}

In the second part, the opinions of the participant students about the application were discussed. The answers to the questions of application evaluation and self-evaluation have shown that 45 students have positive thoughts about the application of oral history. Only one student reported that $\mathrm{s} / \mathrm{he}$ did not like this method because $\mathrm{s} /$ he did not like doing homework. Students who found the practice positive mentioned various contributions of oral history interview. Table 2 summarizes the contributions of oral history practice to students.

Table 1. Results of oral history method in teaching phenomenon of migration $(f)$

\begin{tabular}{lcc}
\hline \multicolumn{1}{c}{ Results } & İzmir & Tekirdăg \\
\hline The students correctly learned the causes and effects of migration. & 21 & 25 \\
\hline The students have learned correctly, when and where the people migrated from. & 15 & 20 \\
\hline The students correctly learned where people migrated and from where they came from. & 5 & 5 \\
\hline The students learned correctly only when the source people migrated. & 1 & - \\
\hline
\end{tabular}


Table 2. Contributions of Oral History Practice to Students $(f)$

\begin{tabular}{lcc}
\hline \multicolumn{1}{c}{ Contributions of Oral History Practice } & İzmir & Tekirdăg \\
\hline It gave me the opportunity to know my family better. & 17 & 5 \\
\hline It made me realize the difficulties that my family encountered in the past. & 15 & 8 \\
\hline I realized that living conditions in the past were more difficult. & 5 & 10 \\
\hline I compared my opportunities with conditions in the past. & 4 & 9 \\
\hline It helped me to develop empathy. & 6 & 8 \\
\hline It helped me to appreciate the value of my living conditions. & 4 & 4 \\
\hline I realized changing and ongoing situations (change and continuity). & 3 & 4 \\
\hline It allowed me to be grateful for my family. & 3 & 2 \\
\hline
\end{tabular}

Based on the information in Table 2, one of the most important contributions of the application to the students was that they had the opportunity to get to know their families better. Yet, they did not only focus on the causes and consequences of migration but also on the history of their family. This helped them to understand the difficulties and living conditions of their families in the past. For example, Onur from the İzmir group explained the role of the interview in learning the details of his family as follows: "The interview helped me to learn more about my family. I was wondering that how did they come here or did they have trouble, and I got the answers. I understood the life of my family there and understood the difficulties of life." Similarly, Begüm from the İzmir group stated that: "While I was listening to my family's history, I felt myself there. When I listened to them, I learned more about them", and she emphasized that the meeting enabled her to get more detailed information about her family.

Students, who got information about the living conditions in the past, compared these conditions with their present lives, so they perceived change and continuity. The opinions of some students are as follows:

"While I was listening to my grandfather, I compared his present and previous life." (Serpil, İzmir)

"Through the interview I made, I learned that the conditions were difficult in the past, and it made me compare them with our present lives." (Ceren, Tekirdağ)

"This migration type has enabled me to understand the change from past to present." (Sudenaz, Tekirda $\breve{g})$

During the interviews, students develop empathy with their families and began to respect them more. Zeynep from the Tekirdag group explained what the migration story of her family made her think: "I was really happy when I heard about my father's migration story. Because it was a big decision for my father. He went through many adventures. I have realized that life is very difficult in every aspect and that we should be thankful for our current status."

The findings in this part show that oral history application has contributed to students in various aspects. Thanks to the application, students got more detailed information about their families and began to respect and be grateful to them more. In addition, they perceived change and continuity by comparing the conditions in past and now.

\subsection{Information that Students Learned about the Migration Experiences of Their Families}

The third part is created by analyzing the data sources and consists of the information that the students learn about the migration process of their families. This information was examined under different headings.

\subsubsection{Approaches of Local People}

In oral history interviews, students first learned that how local people welcomed their families when they migrated.

Table 3. Approaches of Local People $(f)$

\begin{tabular}{ccc}
\hline Approaches & İzmir & Tekirdă̆ \\
\hline Tolerant & 21 & 24 \\
\hline Negative & - & 1 \\
\hline Indecisive & - & - \\
\hline Total & 21 & 25 \\
\hline
\end{tabular}

As can be understood from the abovementioned information, the families of the students who migrated to both İzmir and Tekirdağ were welcomed well by the local people.

\subsubsection{Problems Encountered in Migrated Places}

People who migrate from a place where they have been living for a long time to another city are likely to face various problems. As a matter of fact, the families of the students experienced some problems in the places where they migrated to. These problems are shown in table 4:

Table 4. Faced Problems in Migrated Places $(f)$

\begin{tabular}{ccc}
\hline Problems & İzmir & Tekirdă̆ \\
\hline There is no problem. & 12 & 5 \\
\hline Adaption problems & 3 & 7 \\
\hline Financial inadequacies & 4 & 1 \\
\hline Sense of foreignness & 1 & 4 \\
\hline Renting a house & 1 & 2 \\
\hline Cultural differences & 1 & 2 \\
\hline Other problems & - & 4 \\
\hline Total & 21 & 25 \\
\hline
\end{tabular}


The problems included in the table show that people experienced adaptation problems, economic inadequacies, feeling of being a stranger, not being able to find a place to stay, and cultural differences. On the other hand, there are many people (12), who did not encounter any problems. Some of them underlined the support of relatives in the solution of problems. For example, four people who migrated to İzmir and Tekirdağ got over the adaptation process without any problems through the support of their relatives. Some people did not experience any problems because they had no economic problem. On the contrary, those who had economic problems experienced some of the abovementioned problems.

\subsubsection{Differences between Migrated Places and Hometown}

People who migrate from one place to another compare their previous settlement with the new settlement. In a study conducted by Lalli (1992), urban identity was reported to be composed of several sub-dimensions and stages, such as comparison, familiarity, commitment, past, and future. According to this, in the first stage of the formation of the urban identity, which is called comparison, individuals or groups evaluate their hometown's distinctive and differentiating characteristics from other cities [as cited Göregenli, Karakuş, Kösten \& Umuroğlu [13]. The families of the students compared the cities where they migrated to with their hometowns in terms of distinctive features. As a result, they have found the following differences in Table 5.

Examination of the results obtained by the students has revealed that source people have drawn attention to the difference in terms of job opportunities. It can be further seen that people and neighborhood relations, population, economic activities, service standards, air pollution, educational opportunities, and cultural diversity are compared between the two places.

\subsubsection{Perception of the Consequences of Migration}

The students also learned about the perception types of the consequences of migration in their study. When the results are analyzed, families perceive changes caused by migration positively. The positive changes made them forget the negative consequences emphasized in the previous heading (Differences between Migrated Places and Hometown). Three people who migrated to İzmir and one person who migrated to Tekirdağ considered the consequences of migration as negative. Those three people who were not happy because of their migration to İzmir emphasized homesickness and some of the problems they encountered in their business life. While a person who migrated to Tekirdağ said that, s/he was unhappy because his/her living standards were better in her hometown. The results on this section are given in table 6 .

The results in the table are based on oral history interviews of the students. According to other important results not reflected in the table, all of the people who believe that migration had positive consequences for them (18) think that their living standards have increased. Moreover, migration has provided important changes not only in the economy but also in a positive mindset. For example, one of the source people who believed that migration had positive consequences for them stated that $\mathrm{s} /$ he realized after the migration that $\mathrm{s} / \mathrm{he}$ could send his/her daughter to school and his/her perspective towards sending his/her daughter to school was changed. Another source person reported that the point of view towards women changed and the value of the woman was understood. As it is seen, migration has many consequences, including sociological, psychological and mental, as well as its economic consequences.

Table 5. Differences between Hometown and Migrated Places $(f)$

\begin{tabular}{cccc}
\hline Features & Hometown & İzmir & Tekirdăg \\
\hline Job Opportunities & Limited (14) & Wide (14) & Wide (22) \\
\hline Human Relations & Candid relationship (11) & $\begin{array}{c}\text { Formal relationship } \\
\text { (3) }\end{array}$ & Formal relationship (8) \\
\hline Neighborhoods Relations & Strong (5) & Weak (2) & Weak (2) \\
\hline Population & Rare(4) & Intensive (3) & Intensive (2) \\
\hline Economy Activity & Agriculture-Based (3) & Industry-Based (2) & Industry-Based (2) \\
\hline Service Standards & Low (2) & High (2) & High (2) \\
\hline Air Pollution & Low (2) & Intensive (2) & Intensive (2) \\
\hline Educational Opportunities & Limited (4) & Wide (2) & Wide (2) \\
\hline Cultural Diversity & Low (6) & Much (3) & Much (3)
\end{tabular}

Table 6. Perception Forms of Migration Results $(f)$

\begin{tabular}{ccc}
\hline Perceptions & İzmir & Tekirdă \\
\hline Positive & 18 & 24 \\
\hline Negative & 3 & 1 \\
\hline Indecisive & - & - \\
\hline Total & 21 & 25 \\
\hline
\end{tabular}


Some students observed the results mentioned by the source people and gave statements based on them. Referring to the results of the migration for her mother, İrem said: "She has found what she hopes for: a spouse who took care of his house and a social environment with every opportunity despite being unemployed. Her daughter is also with her and she cares for her education." İrem's mother migrated from Ukraine to İzmir after being married and got better living conditions.

Considering the results presented in the Results section, the application of oral history has enabled students to explore the various dimensions of migration, compare their families' past and present conditions, and respect their families more.

\section{Discussion, Conclusions, and Recommendations}

The results of this oral history practice, which was carried out in two provinces that receive a great number of migrants and in two schools in relevant provinces to which mostly workers' children attend, has shown that the relevant method has provided students to understand the economic, sociological, cultural and personal dimensions of the phenomenon of migration. Detailed evidence for this has been presented in the Results section. Furthermore, the students and source participants stated that they were satisfied with the application of oral history and that the study helped them to establish a meaningful connection between the generations.

Furthermore, oral history application is considered to provide various contributions to students. Academically, this application has allowed students to learn and discuss the causes (job, health, terror, etc.) and consequences of migration together with its several dimensions. In particular, the students have learned their recent history because they have interviewed with their families. Students who have learned this information for the first time began to respect their families more. Yet, they have compared the opportunities of their families in the past with the opportunities they have now and put themselves into their shoes (empathizing). This function of oral history was also included in the study by Horn [15]. In this study, oral history was reported to allow the comparison of the past with the present, and hence to develop a sense of gratitude towards the family. Furthermore, as in the study of Dere \& Alkaya [9], since the students interviewed with their family members and close relatives, it was not difficult for them to find a source person in the present study.

On the other hand, as stated in many previous studies $[6,18,38]$, the contribution of oral history to the perception of change and continuity was also revealed in this study. Participating students had the opportunity to perceive and interpret the change caused by migration. Based on this evaluation, the changes caused by the migration - better living standards for families was perceived as a positive change. In addition to perceiving change and continuity, students have developed basic historical thinking skills such as perceiving time and chronology and establishing a cause-effect relationship. These results support the close relationship between oral history and historical thinking skills, expressed by Lanman \& Wendling [20], Van Nieuwenhuyse[37] and Horn[15].

On the other hand, in oral history application, the students have learned the experiences of their families in the process of migration in detail. Based on the results obtained through the interviews carried out by them, the families who migrated to İzmir and Tekirdağ were welcomed positively by the local people in both provinces. In addition, those who migrated to İzmir did not encounter any major problems during the migration process, while adaptation was being the most important problem for those who migrated to Tekirdağ. Urban comparison, which was identified as the first stage of the urban identity formation process by Lalli (1992), was seen to be also made by the families of the students. Because the source people, in the oral history interviews, compared the places, where they migrated from (their hometowns) and migrated to (İzmir and Tekirdağ). In these comparisons, it was understood that almost all the source persons migrated due to economic reasons (e.g. job opportunities, service standards, etc.). It was observed that they used positive expressions about İzmir and Tekirdağ.

In conclusion, in light of the results of the study, it can be said that oral history is an effective method in learning and understanding the various dimensions of migration. In particular, students have studied and evaluated the phenomenon of migration over their families, which has increased its effect even more. They studied the subject in a more willing and curious way because they have established a direct connection between the phenomenon of migration and their own lives.

Considering the results obtained, some recommendations may be given to teachers who want to use the oral history method in social studies courses. First of all, social studies teachers should use the oral history method more actively in their lessons. In many subjects included in the Social Studies Curriculum, students will not encounter any problem regarding finding a source person since they can directly get in touch with their families. Finally, the type of oral history interviews (written or oral interview) that will be made by the students should be decided by taking the conditions of the students into consideration.

\section{REFERENCES}

[1] Akgür, Z. G. (1997). Türkiye'de kırsal kesimden kente göç ve bölgelerarası dengesizlik (1970-1993). (V. 201). Ankara: T.C. Kültür Bakanlığı. 
[2] Archive of Immigrants Voices, (2018). Online available from https://archiveofimmigrantvoices.omeka.net/education

[3] Anadolu Agency, (2018). Uluslararası Göç İstatistikleri, 2017 [International Migration Statistics, 2017]. Online available from https://www.aa.com.tr/

[4] Baklacıoğlu, N. Ö. (2010). Dış Politika ve Göç, Yugoslavya'dan Türkiye'ye Göçlerde Arnavutlar (1920-1990). İstanbul: Derin Yayınları.

[5] Balcıoğlu, İ. (2007). Sosyal ve psikolojik açıdan göç. İstanbul: Elit Kültür Yayınları.

[6] Bertram, C., Wagner, W. \& Trautwein, U. (2017). Learning historical thinking with oral history interviews: A cluster randomized controlled intervention study of oral history interviews in history lessons. American Educational Study Journal, 54(3), 444-484.

[7] Dere, İ. (2018). Sosyal bilgiler öğretim programlarında (2005 ve 2017) sözlü tarih [Oral history in 2005 and 2017 social studies circulia programs]. Milli Eğitim Dergisi, 47(220). (In Press).

[8] Dere, İ. \& Dinç, E. (2018). Yapılandırmacı bir öğrenme ve öğretme yöntemi olarak sözlü tarihin sosyal bilgiler derslerine entegrasyonu. İп̈nӥ Üniversitesi Ĕ̈itim Fakültesi Dergisi, 19 (2), 115-127 DOI: 10.17679/inuefd.335686

[9] Dere, İ. \& Alkaya, S. (2017). Sosyal bilgiler derslerinde tıp tarihi konularının sözlü tarihle öğretimi [teaching of medicine history topics by using oral history in social studies courses]. Journal of History Culture and Art Study, 6(6), 504-522.

[10] Erdilek, N. (2006). Türkiye'de göç araştırmalarında sözlü tarih metodu. İlyasoğlu, A. \& Kayacan, G. (Ed.), Kuşaklar Deneyimler Tanıklıklar. Türkiye'de Sözlü Tarih Çalıșmaları Konferansı (26-27 September 2003), 79-85. İstanbul: Tarih Vakfi Yurt.

[11] Diekema, M. (1989). Oral history and the young child (Unpublished Master Thesis). Calvin College.

[12] Erkan, R. (2005). Güneydoğu Anadolu Bölgesi'nin sosyal yapısı ve değișme eğilimleri (Vol. 61). Kalan Yayınları.

[13] Göregenli, M., Karakuş, P., Kösten, E. Y. Ö. \& Umuroğlu, I. (2014). Mahalleye bağlılık düzeyinin kent kimliği ile ilişkisi içinde incelenmesi [The spatial dimension in migration study: Cultural and spatial integration]. Türk Psikoloji Dergisi, 29(73), 73.

[14] Güler, E. (2012). Sözlü tarih anlatılarında Çanakkale merkeze Girit'ten göçler: 'Giritli, başı bitli...'. Çanakkale Araștırmaları Türk Yıllı̆̆ı, Year: 10, Autumn, N: 13, 43-58.

[15] Horn, K. (2014). Oral history in the classroom: Clarifying the context through historical understanding. Yesterday and Today, (11), 72-83.

[16] Immigration History Study Center, (2018). Educator Resources. Online available from https://cla.umn.edu/ihrc/

[17] Johnson, A. P. (2015). Eylem araştırması el kitabı (Translation Eds. Uzuner, Y. \& Anay, M. Ö.). Ankara: Anı Yayınc1lik

[18] Kabapınar, Y. \& İncegül, S. (2016). Değişim ve süreklilik bağlamında oyun ve oyuncağa bakmak: Bir sözlü tarih çalışması [Child games and toys within the framework of change and continuity: An oral history study]. Turkish History Education Journal, 5(1), 74-96.

[19] Karpat, K. H. (2010). Osmanlı'dan günümüze etnik yapılanma ve göçler (Trans. Bahar Tırnakçı). İstanbul: Timaş Yayınları.

[20] Lanman, B. A. \& Wendling, L. M. (2018). Introductory strategies for conducting oral history interviews with Vietnam veterans. Online available from https://edsitement.neh.gov/

[21] Library of Congress, (2018). Immigration and oral history. Online available from http://www.loc.gov/

[22] Maxwell, J. A. (2018). Nitel araştırma tasarımı etkileşimli yaklaşım (Trans. Ed. Çevikbaş, M.). Ankara: Nobel Yayınc1lık.

[23] Ministry of National Education, (2005). Sosyal bilgiler 6.-7. sınıflar ögretim programı. Ankara: TTKB Yayınları.

[24] Ministry of National Education, (2017). Sosyal bilgiler dersi ögretim programı (ilkokul ve ortaokul 4, 5, 6 ve 7. sinıflar). Ankara: TTKB Yayınları.

[25] Özer, İ. (2004). Kentleşme, kentlileşme ve kentsel değişme. Bursa: Ekin Kitabevi.

[26] Özsoy, İ. (2007). İki vatan yorgunları: mübadelenin acısın yaşayanlar anlatıyor. İstanbul: Bağlam Yayıncılık.

[27] Refugees Association, (2018). Türkiye'deki Suriyeli Sayısı Ağustos 2018 [Syrian Refugees Numbers in Turkey August 2018). Online available from https://multeciler.org.tr/

[28] Richter, M. (2005). Geldiler ve kaldilar: Almanya Türkleri'nin yaşam öyküleri. İstanbul Bilgi Üniversitesi Yayınları.

[29] Ritchie, D. A. (2015). Doing oral history. New York: Oxford University Press.

[30] Sezer, A. \& Şanl1, C. (2017). Coğrafya öğretim programında ve ders kitaplarında göç olgusu [The phenomenon of migration in curriculum and textbooks of geography lesson]. Marmara Coğrafya Dergisi, (36), 16-25.

[31] Somekh, B. (2006). Action research: a methodology for change and development: a methodology for change and development. McGraw-Hill Education (UK).

[32] Tevfik, İ. (2014). Insan ve mekân yüzüyle mübadele: 1923 'ten bugüne zorunlu göç. İstanbul: İnkılap Kitabevi.

[33] Thompson, P. (1999). Geçmişin sesi [Voice of the past] (Trans. Şehnaz Layıkel). İstanbul: Tarih Vakfı Yurt Yayınları.

[34] Türkcan, B. (2017). Suriye krizi sonrası göçün Türkiye'de bölge ekonomilerine etkileri [The Impacts of international migration on regional economies in Turkey]. Adlyaman Üniversitesi Sosyal Bilimler Dergisi, 9(26), 769-795.

[35] Uyar, V. (2018). 2017 İç Göç Dalgası [2017 Internal Migration Wave]. Online available from http://www.dogrulukpayi.com/

[36] Van Nieuwenhuyse, K. (2017). Where macro and micro histories meet: Position, trumps, and pitfalls of family 
history as a form of oral history in flemish education. In Oral history and education (pp. 167-185), Llewellyn, K. R. \& Ng-A-Fook, N. (Eds.). Palgrave Macmillan, New York.

[37] von Heyking, A. (2017). Developing student teachers' historical thinking: Oral history in teacher education. In Oral history and education (pp. 299-316), Llewellyn, K. R. \& Ng-A-Fook, N. (Eds.). Palgrave Macmillan, New York.

[38] Yalçın, C. (2004). Göç sosyolojisi. Ankara: Anı Yayıncılık.

[39] Yıldırım, A. \& Şimşek, H. (2008). Nitel araştırma yöntemleri [Qualitative study methods]. Ankara: Seçkin Yayınc1lik.

\footnotetext{
${ }^{\text {i }}$ A preliminary version of this study was presented as an oral presentation at the V. International Symposium on History Education (ISHE 2018) held in Istanbul, Turkey, May 10-12, 2018.

I really appreciate social studies teachers Mehmet Sami Başak and Funda Gülpınar who helped me in the research.
} 